\title{
Hormonal control of the transcription factor Pax8 and its role in the regulation of thyroglobulin gene expression in thyroid cells
}

\author{
A Mascia, L Nitsch, R Di Lauro ${ }^{1}$ and M Zannini \\ CEOS, CNR and Dipartimento Biologia e Patologia Cellulare e Molecolare, Via Pansini 5, 80131 Naples, Italy \\ ${ }^{1}$ Stazione Zoologica A Dohrn, Villa Comunale, 80121 Naples, Italy \\ (Requests for offprints should be addressed to M Zannini, Dipartimento di Biologia e Patologia Cellulare e Molecolare, Universita di Napoli Federico II, \\ via Pansini, 5-80131 Naples, Italy; Email: stella@alpha.szn.it)
}

\begin{abstract}
The transcription factor Pax8 plays an important role in the expression of the differentiated phenotype of thyroid follicular cells. It has recently been shown that Pax8 is necessary for thyroglobulin $(\mathrm{Tg})$ gene expression in the fully differentiated rat thyroid cell line PC. We have used the PC model system to investigate the role of Pax8 as a mediator of TSH regulation of $\mathrm{Tg}$ gene expression. We have demonstrated that Pax8 expression, as well as Tg expression, is severely reduced in cells grown in the absence of hormones and serum. The re-addition of TSH or forskolin to the culture medium is able to restore to wild-type levels the expression of both Pax8 and Tg. We have determined that the action of TSH/forskolin on Pax8 is at the transcriptional level. However, the re-expression of Pax8 can be observed several hours before that of $\mathrm{Tg}$,
\end{abstract}

suggesting that either another factor is needed or that Pax8 itself must be post-translationally modified by a newly synthesized protein to become active. To distinguish between these two possibilities we have stably transfected into PC cells an exogenous Pax8 that is expressed independently of TSH. Our results indicate that in these cells the $\mathrm{Tg}$ promoter is still dependent on TSH despite the constitutive presence of Pax8. Furthermore, we also show that in this condition $\mathrm{Tg}$ gene transcription requires de novo protein synthesis. In conclusion, TSH regulates the expression of Pax8 at a transcriptional level and also regulates the activity of Pax 8 by controlling the expression of one or more as yet unknown factors.

Journal of Endocrinology (2002) 172, 163-176

\section{Introduction}

Thyrocytes, the most abundant cell population in the thyroid gland, represent a useful model system to study the mechanisms for establishment and maintenance of celltype-specific patterns of gene expression. Thyrocytes are mainly involved in the synthesis of thyroid hormones and are characterized by the expression of specific genes such as thyroglobulin (Tg) and thyroperoxidase (TPO), which are exclusively expressed in this cell type (Damante \& Di Lauro 1994, Damante et al. 2000). Tg is a huge protein of $330 \mathrm{kDa}$ that is secreted by thyrocytes and is accumulated in the follicular lumen where it is iodinated and is the precursor to thyroid hormones. The promoter of the $\mathrm{Tg}$ gene has been extensively studied and three transcription factors have been cloned that specifically bind and activate this promoter (Damante \& Di Lauro 1994, Damante et al. 2000). The three factors are TTF-1 (thyroid transcription factor-1), TTF-2 (thyroid transcription factor-2) and Pax8. TTF-1 is an homeodomain-containing protein expressed in embryonic diencephalon, thyroid and lung (Lazzaro et al. 1991); TTF-2 is a forkhead domain-containing protein expressed in pituitary and thyroid (Zannini et al.
1997), and Pax8 is a member of the murine Pax family of paired domain-containing genes, and it is expressed in kidney, in the developing excretory system and in the thyroid (Plachov et al. 1990).

The main physiological stimulus regulating thyroid function is given by thyrotropin (TSH) produced by the pituitary gland. Like many other hormones, TSH exerts its function through a $G$ protein-coupled receptor, the TSH receptor (TSHR), which relies on the associated $G$ protein to transmit and amplify the signal inside the cell. In rat thyroid cells, TSH-mediated activation results primarily in cAMP production that is likely to play a crucial role in the onset of differentiation both in vitro and in vivo. Indeed cAMP agonist, for instance forskolin (FSK), can mimic TSH-induced differentiation. The presence of TSH is also required for the maintenance of the differentiation status, since withdrawal of TSH for a prolonged time causes loss of thyroid-specific gene expression in cultured cells. Several studies have led to the conclusion that TSH regulates the expression of the $\mathrm{Tg}$ gene by determining its rate of transcription (Avvedimento et al. 1984, Van Heuverswyn et al. 1984, 1985, Santisteban et al. 1987). A number of in vitro studies, in which cultured thyrocytes 
were used, have shown that lack of TSH leads to a drastic reduction in Tg mRNA and that re-addition of TSH is able to reactivate Tg transcription (Chebath et al. 1979, Tosta et al. 1983, Nagayama et al. 1989, Roger et al. 1997). In vivo studies in the rat also suggested that TSH controls $\mathrm{Tg}$ gene transcription via the interaction with its receptor on thyrocytes, and that cAMP is a physiological mediator of this effect (Van Heuverswyn et al. 1984, 1985). However, no cAMP-responsive elements have been found in the rat Tg promoter region (Gerard et al. 1989, Lee et al. 1991). The molecular mechanism by which TSH controls Tg gene expression, and the potential involvement of the transcription factors which are known to bind to its promoter, have not been elucidated yet (Santisteban et al. 1992, Van Renterghem et al. 1995, 1996, Kambe et al. 1996, Ortiz et al. 1997). In addition, it must be said that there is a significant variability among the experiments performed in the different model systems in the extent of $\mathrm{Tg}$ regulation by TSH. This variability is possibly related to the different hormonal backgrounds, in particular to the presence or absence of serum or insulin in the culture conditions, and to the length of time of TSH deprivation.

We have focused our studies on the role played by the transcription factor Pax8 that is expressed in the thyrocytes of either embryonic or adult thyroid gland, as well as in differentiated thyroid cells in culture. Pax 8 was initially shown to bind to and to activate transcription from the TPO promoter in non-thyroid cells, thus identifying for TPO the first target for Pax8 action (Zannini et al. 1992). Pax8 also binds to a single site on the Tg promoter, and was recently shown to activate $\mathrm{Tg}$ gene expression through a thyroid-specific mechanism (Pasca Di Magliano et al. 2000). In addition, Pax8 appears to be also involved in the thyroid-specific expression of the rat sodium/iodide symporter (NIS) gene (Ohno et al. 1999). Interestingly, in Pax8 knockout mice the thyroid gland is much smaller than normal and lacks follicles (Mansouri et al. 1998). Thyroid follicular cells are absent in these mice and the expression of thyroid-specific markers, such as $\mathrm{Tg}$ and TPO, cannot be detected (Mansouri et al. 1998). These in vivo studies led to the conclusion that Pax8 is needed for proper differentiation of thyrocytes. Mutations in the Pax8 gene have also been associated with congenital hypothyroidism in humans (Macchia et al. 1998). Patients carrying the mutations are affected by thyroid dysgenesis, indicating an important role for this gene in thyroid organogenesis.

A correlation between low levels of expression of Pax8 and lack of thyroid differentiation has been proposed by the study of the transformed FRTL5/TA thyroid cells (Van der Kallen et al. 1996). Moreover, a direct demonstration that Pax8 plays a key role in the control of thyroid-specific gene expression has been recently obtained by studying the transformed cell line PcPy (Pasca Di Magliano et al. 2000). Very little is known about Pax8 transcriptional and post-transcriptional regulation.
Recently, it has been published that in FRTL5 rat thyroid cells (Fabbro et al. 1998, Medina et al. 2000) as well as in canine thyroid cells in culture (Van Renterghem et al. 1996) TSH regulates Pax 8 synthesis.

We have investigated the role of Pax8 as a mediator of TSH action in thyrocytes. To this purpose we used as a model system rat thyrocytes in culture, the PC cells that express thyroid-specific genes such as Tg, TPO, NIS and TSH receptor (Fusco et al. 1987), and the thyroid-specific transcription factors TTF-1, TTF-2 and Pax8. We show here that in PC cells TSH regulates the expression of $\mathrm{Tg}$ and Pax8 genes at a transcriptional level by a cAMPmediated mechanism. The delayed reactivation of Tg with respect to Pax8 gene suggested that another factor is required or that Pax 8 protein needs to be modified to become active. By studying stable clones of PC cells expressing constitutively an exogenous Pax8, we determined that in the absence of TSH the Tg promoter is transcriptionally inactive despite the presence of Pax8. We also demonstrated that under these conditions Pax8 is inactive and that TSH-dependent de novo protein synthesis is required for its activation, thus indicating the requirement for one or more additional factor(s).

\section{Materials and Methods}

\section{Plasmids}

The pEF-Pax8-myctag construct was generated by PCR amplification of the mouse Pax8-coding region with a $5^{\prime}$ primer and a $3^{\prime}$ primer containing at their ends the BamHI and EcoRI sites respectively. The fragment was then subcloned into the corresponding sites of the expression vector EFplink that was previously modified with the addition of a myc tag by $\mathrm{R}$ Treisman (ICRF, London, UK). The construct was sequenced to control the fidelity of the frame between the myc tag and the inserted fragment.

The plasmids used in transient transfection experiments have been previously described and were as follows: pTACAT3 (Sinclair et al. 1990), and CP5-CAT (Missero et al. 1998).

CMV-CAT and RSV-LUC plasmids were used for control activities and for normalization in the transient transfection respectively.

The DNA of all the plasmids was prepared by Qiagen cartridges (Qiagen, Milan, Italy) and used for cell transfection.

\section{Cell culture and transfection}

The PC cell line has been previously described (Fusco et al. 1987). Both PC cells and PC-Pax8-myctag stable clones were cultured in Falcon plastic dishes (Becton Dickinson Labware, Lincoln Park, NJ, USA) as described 
by Ambesi-Impiombato \& Coon (1979). The complete medium consisted of Coon's modified Ham's F12 medium (Sigma Chemical Co., Milan, Italy) supplemented with $5 \%$ calf serum (Life Technologies, Karlsruhe, Germany) and six hormones $(6 \mathrm{H})$ and growth factors as described by Ambesi-Impiombato \& Coon (1979). The starvation medium consisted of Coon's modified Ham's F12 medium supplemented only with $0 \cdot 2 \%$ BSA.

Transfections were carried out with the Lipofectin reagent (Life Technologies) as suggested by the manufacturer with minor modifications. Briefly, $3 \mathrm{~h}$ prior to transfection the medium of subconfluent cells, cultured either in complete medium or in starvation medium, was replaced with OPTIMEM 1 (Life Technologies). The DNA/liposome ratio was 1:5 in all the experiments.

For transient transfection, cells were collected after $48 \mathrm{~h}$ to determine either the levels of CAT protein with a CAT enzyme-linked immunosorbent assay kit (Boehringer, Monza, Italy) or LUC activities as described previously (Zannini et al. 1997).

To obtain stable clones, PC cells were transfected with plasmid pEF-Pax8-myctag and a plasmid containing the neomycin-resistance gene under the RSV promoter (ratio 20:1). Cells were selected with $300 \mu \mathrm{g} / \mathrm{ml}$ G418 (Sigma). After 2 weeks, G418-resistant clones were isolated, expanded and examined by immunofluorescence.

\section{RNA extraction and Northern blot analysis}

Total RNA was prepared by the acid guanidinium thiocyanate/phenol procedure (Chomczynski \& Sacchi 1987).

Thirty micrograms of total RNA were electrophoresed on a $1 \%$ agarose gel containing $3 \cdot 7 \%$ formaldehyde and $20 \mathrm{mM}$ morpholinepropane sulfonic acid buffer. RNA was then blotted onto nylon membranes (Hybond-N; Amersham-Pharmacia, Milan, Italy) with $20 \times$ SSC, and hybridization and washing were carried out according to Church \& Gilbert (1984).

The blot was probed with rat cDNA fragments derived by restriction digestion of $\mathrm{Tg}$ - and Pax8-coding sequences, and labeled by random priming with $\left[\alpha-{ }_{-}^{32} \mathrm{P}\right] \mathrm{dATP}$ and $\left[\alpha_{-}{ }^{32} \mathrm{P}\right] \mathrm{dCTP}$ (Amersham Life Science, Amersham, Bucks, UK). A $300 \mathrm{bp}$ fragment derived from the 3' region of rat glyceraldehyde-3-phosphate dehydrogenase was used as control.

\section{$R T-P C R$}

One nanogram of total RNA prepared from the different cell lines was used to synthesize cDNA using the Superscript One-Step RT-PCR system (Life Technologies) with gene-specific primers. The primers used to amplify the $\mathrm{Tg}$ transcript were TG-2 and TG-4 (Mascia et al. 1997), which map in the first and second exon of the $\mathrm{Tg}$ gene respectively. The reactions were set up according to the protocol of the kit, and the conditions used were as previously described (Mascia et al. 1997). An aliquot of the total volume of the PCR reactions was analyzed on a $1 \%$ agarose gel.

\section{Cell extracts and Western blot}

PC and PC-Pax8-myctag cells were cultured in $100 \mathrm{~mm}$ plastic dishes in complete medium or for 7 days in starvation medium. Cells were washed twice with ice-cold PBS and scraped in $1 \mathrm{ml}$ of $40 \mathrm{mM}$ Tris $\mathrm{pH} 7 \cdot 5,1 \mathrm{mM}$ EDTA, $150 \mathrm{mM} \mathrm{NaCl}$. Cell extracts were prepared as previously described (Zannini et al. 1992), and protein concentration was determined using the Bio-Rad protein assay (Bio-Rad). Forty to eighty micrograms of total extract for Pax8, or $10 \mu \mathrm{g}$ for $\mathrm{Tg}$, were solubilized in reducing Laemmli buffer, boiled for $5 \mathrm{~min}$ and analyzed by SDS-10\% PAGE or SDS-7\% PAGE. Gels were blotted onto Immobilon P (Millipore, Bedford, MA, USA) in a Bio-Rad apparatus (Bio-Rad, Milan, Italy) for 16-24 h.

Immunodetection was performed using an anti-Pax8 antibody, an anti-myc antibody and an anti-Tg antibody diluted in $150 \mathrm{mM} \mathrm{NaCl}, 20 \mathrm{mM}$ Tris-HCl, pH 7.5 containing $0.5 \%$ non-fat dry milk (Bio-Rad) at 1:1000, 1:500 and 1:2500 respectively. Subsequently, the filters were developed using an enhanced chemiluminescence detection method (Amersham) according to the manufacturer's directions.

\section{Immunofluorescence}

Cells were cultured directly on $12 \mathrm{~mm}$ diameter glass coverslips in complete medium or in starvation medium. Where indicated, TSH $(1 \mathrm{mM})$ or FSK/3-butyl-1methylxanthine (IBMX) $(10 \mu \mathrm{M} / 1 \mathrm{mM})$ was added at different times. To visualize Tg, Pax8-myctag or Pax8, the cells were fixed for $20 \mathrm{~min}$ with $4 \%$ paraformaldehyde (Sigma) in PBS containing $0.9 \mathrm{mM}$ calcium and $0.5 \mathrm{mM}$ magnesium (PBS CM) at room temperature, washed twice in $50 \mathrm{mM} \mathrm{NH}_{4} \mathrm{Cl}$ in PBS CM and twice in PBS CM. Cells were permeabilized for $5 \mathrm{~min}$ in $0.5 \%$ Triton-X 100 (Bio-Rad) in PBS CM and washed twice, for $10 \mathrm{~min}$, in $0 \cdot 2 \%$ gelatin (Sigma) in PBS CM.

Cells were then incubated for $1 \mathrm{~h}$ with the primary antibodies diluted in $0.5 \%$ BSA (Sigma) in PBS. After three washes with $0 \cdot 2 \%$ gelatin in PBS CM, cells were incubated for $20 \mathrm{~min}$ with the appropriate rhodamine- or fluorescein-tagged goat anti-mouse or anti-rabbit secondary antibody (Jackson ImmunoResearch, West Grove, PA, USA), diluted $1: 50$ in $0.5 \%$ BSA in PBS. To visualize actin filaments, permeabilized cells were incubated with a 1:70 dilution of rhodamine-conjugated phalloidin (Sigma) for $20 \mathrm{~min}$. After final washes with PBS, the coverslips were mounted on a microscope slide using a $50 \%$ solution 
of glycerol in PBS and examined with a Zeiss Axiophot microscope (Zeiss, Milan, Italy). NIS was visualized as described (Paire et al. 1997).

\section{Antibodies and reagents}

The rabbit polyclonal antibody to rat $\mathrm{Tg}$ was described in Mascia et al. (1997); the polyclonal anti-Pax8 antibody was raised against a peptide derived from Pax8-coding region and was described in De Vita et al. (1998); rabbit antiserum to rat NIS (pAb 716) was a kind gift of B Rousset (Faculté de Médicine Lyon, RTH Laennec, Lyon Cédex, France); anti-c-myc (9E10) monoclonal antibody was from Santa Cruz Biotechnology, Inc. (Santa Cruz, CA, USA); horseradish peroxidase-linked anti-rabbit or anti-mouse antibodies were from Amersham. BSA, TSH, FSK and IBMX were from Sigma.

\section{Results}

TSH deprivation causes loss of expression of $\mathrm{Pax} 8, \mathrm{Tg}$ and NIS genes in cultured rat thyroid cells

To investigate the role of TSH in the expression of thyroid-specific genes, differentiated rat thyroid PC cells were cultured for 7 days in serum-free medium containing either $0 \cdot 2 \% \mathrm{BSA}$ alone, or $0 \cdot 2 \% \mathrm{BSA}$ plus $6 \mathrm{H}$ or $\mathrm{TSH}$. The expression of the thyroid-specific transcription factors Pax8 and TTF-1, and of the thyroid-specific genes Tg and NIS was analyzed by indirect immunofluorescence (Fig. 1). A strong reduction in fluorescence staining of Pax8 (Fig. 1b), Tg (Fig. 1e) and NIS (Fig. 1h) was observed in cells cultured in the absence of hormones with respect to cells cultured in the presence of $6 \mathrm{H}$ (Fig. 1a, d and g). Staining of the three proteins in the presence of $0 \cdot 2 \%$ BSA plus TSH alone was comparable with that in the presence of $6 \mathrm{H}$ (Fig. 1c, fand i). No significant change in TTF-1 staining was detected under any of the culture conditions tested (Fig. 1j-1). TSH deprivation caused, as expected (Tramontano et al. 1982, Westermark \& Portor 1982, Kurihara et al. 1990), a dramatic change in cell shape and microfilament organization (Fig. $1 \mathrm{~m}-\mathrm{o}$ ). The same results were also obtained in the differentiated rat thyroid cell line FRTL5 and when serum was present in the culture medium (data not shown). These data indicate that TSH regulates the expression of Pax8, Tg and NIS genes in rat thyroid cells in culture.

\section{Pax8 and $\mathrm{Tg}$ gene expression is coordinately induced by TSH stimulation}

To determine if Pax 8 and $\mathrm{Tg}$ gene expression was induced with similar kinetics by TSH stimulation, PC cells were cultured for 7 days in medium lacking serum and hormones until both Pax8 and Tg proteins had disappeared.
The cells were then treated with TSH for different lengths of time $(6,24$ or $48 \mathrm{~h}$ ) and $\operatorname{Pax} 8$ and Tg proteins were detected by indirect immunofluorescence (Fig. 2). Pax8 nuclear staining was strongly reduced after serum and hormone starvation (Fig. 2a), could be observed already at $6 \mathrm{~h}$ of TSH treatment (Fig. 2b) and did not significantly increase thereafter (Fig. 2c and d). At variance, Tg staining could be detected only after $24-48 \mathrm{~h}$ of TSH treatment (Fig. $2 \mathrm{~g}$ and $\mathrm{h}$ ). We then asked if the TSH effect was mediated by cAMP. To address this question the same experiment was performed with cells treated with FSK/IBMX instead of TSH. Also in this condition, Pax8 was detected after $6 \mathrm{~h}$ of FSK/IBMX treatment (Fig. 2j), while $24 \mathrm{~h}$ of FSK/IBMX treatment were needed before $\mathrm{Tg}$ became detectable (Fig. 2o). Similar results were obtained by treating cells with cAMP derivatives, such as 8-Br-cAMP (data not shown). The induction of Pax8 and Tg expression was also analyzed by Western blot (Fig. 3A). In good agreement with the immunofluorescence data, in PC cells, after 7 days of starvation, a $6 \mathrm{~h}$ treatment with TSH was sufficient to induce the synthesis of Pax8 protein. At least $24 \mathrm{~h}$ were indeed needed to detect the presence of Tg within the cells. The expression of TTF-1 did not appear to significantly change during starvation or upon TSH treatment (Fig. 3A).

To determine whether TSH regulates the expression of Pax8 at the mRNA level, PC cells were starved of serum and hormones for 7 days and were then treated with TSH for different times. Total RNA was extracted and the appearance of Pax8 and Tg mRNAs was analyzed by Northern blot (Fig. 3B). Pax8 and Tg mRNAs were not detected following the 7 days of starvation while, after $6 \mathrm{~h}$ of TSH stimulation, Pax8 mRNA could already be seen within the cells. Only after $24 \mathrm{~h}$ of TSH treatment was a transcript corresponding to Tg mRNA detected (Fig. 3B). The kinetics of appearance of Pax8 and Tg mRNAs are in good agreement with those of the corresponding proteins, indicating that the reactivation of the two genes is not concomitant and that Pax8 gene is already transcribed and translated several hours before the $\mathrm{Tg}$ gene. These results suggest, on the one hand, that Pax8 protein might be needed before Tg gene expression occurs; on the other hand, the long lag between the expression of the two genes might indicate that additional events are required, other than Pax8 protein synthesis, to fully activate the molecular machinery that promotes $\mathrm{Tg}$ gene transcription.

\section{Pax8 does not restore $\mathrm{Tg}$ gene expression in TSH-starved PC cells}

Several lines of evidence indicate that Pax8 is a transacting factor strictly required for $\mathrm{Tg}$ gene transcription (Fabbro et al. 1998, Pasca Di Magliano et al. 2000). To investigate whether Pax8 presence was indeed sufficient to reactivate $\mathrm{Tg}$ gene expression in the absence of TSH stimulation, the expression vector pEF-Pax8-myctag, which codes for a 

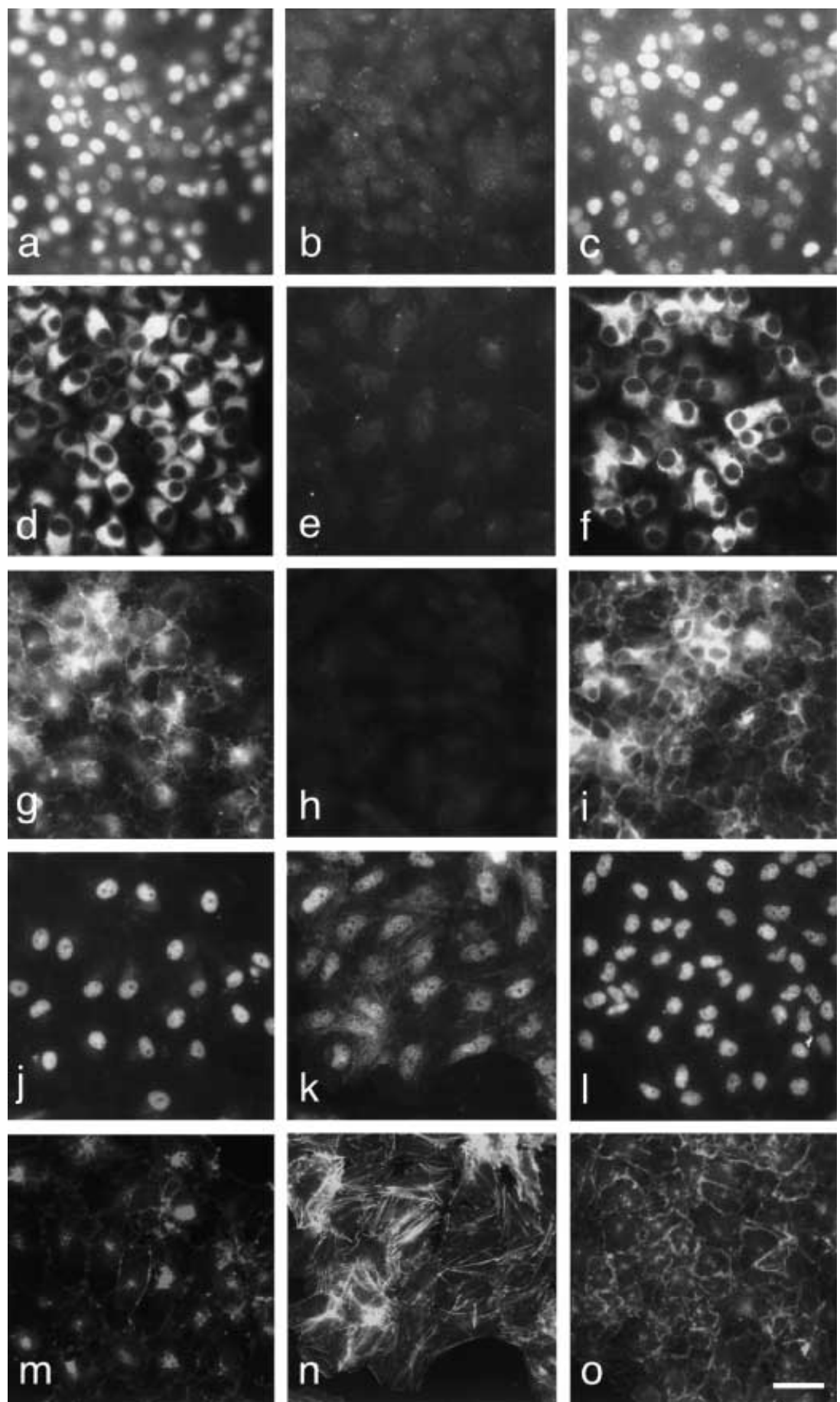

Figure 1 Detection of Pax8, Tg, NIS and TTF-1 by immunofluorescence in PC cells. PC cells were plated on glass coverslips in complete culture medium. The day after, medium was changed and fresh medium containing $0 \cdot 2 \%$ BSA plus $6 \mathrm{H}(\mathrm{a}, \mathrm{d}, \mathrm{g}, \mathrm{j}, \mathrm{m}), 0 \cdot 2 \% \mathrm{BSA}$ alone $(\mathrm{b}, \mathrm{e}$, $\mathrm{h}, \mathrm{k}, \mathrm{n})$ or $0 \cdot 2 \%$ BSA plus $1 \mathrm{mU} / \mathrm{ml} \mathrm{TSH}(\mathrm{c}, \mathrm{f}, \mathrm{i}, \mathrm{l}, \mathrm{o})$ was added. After 7 days of further culture, cells were fixed with formaldehyde, permeabilized with Triton X-100 and stained by immunofluorescence using the anti-Pax8 (a-c), anti-Tg (d-f), anti-NIS (g-i) or anti-TTF-1 (j-l) antibody. The nuclear staining of Pax8 (a), the cytoplasmic staining of Tg (d) and the membrane staining of NIS (g) are lost in the absence of $6 \mathrm{H}(\mathrm{b}, \mathrm{e}, \mathrm{h})$ but retained in the presence of TSH alone $(\mathrm{c}, \mathrm{f}, \mathrm{i})$. No significant change in TTF- 1 staining was observed in the different culture conditions $(\mathrm{j}, \mathrm{k}, \mathrm{I})$. Actin microfilaments were prominent in the absence $(\mathrm{n})$ and disappeared in the presence (m, o) of $\mathrm{TSH}$. Bar $=50 \mu \mathrm{m}$. 

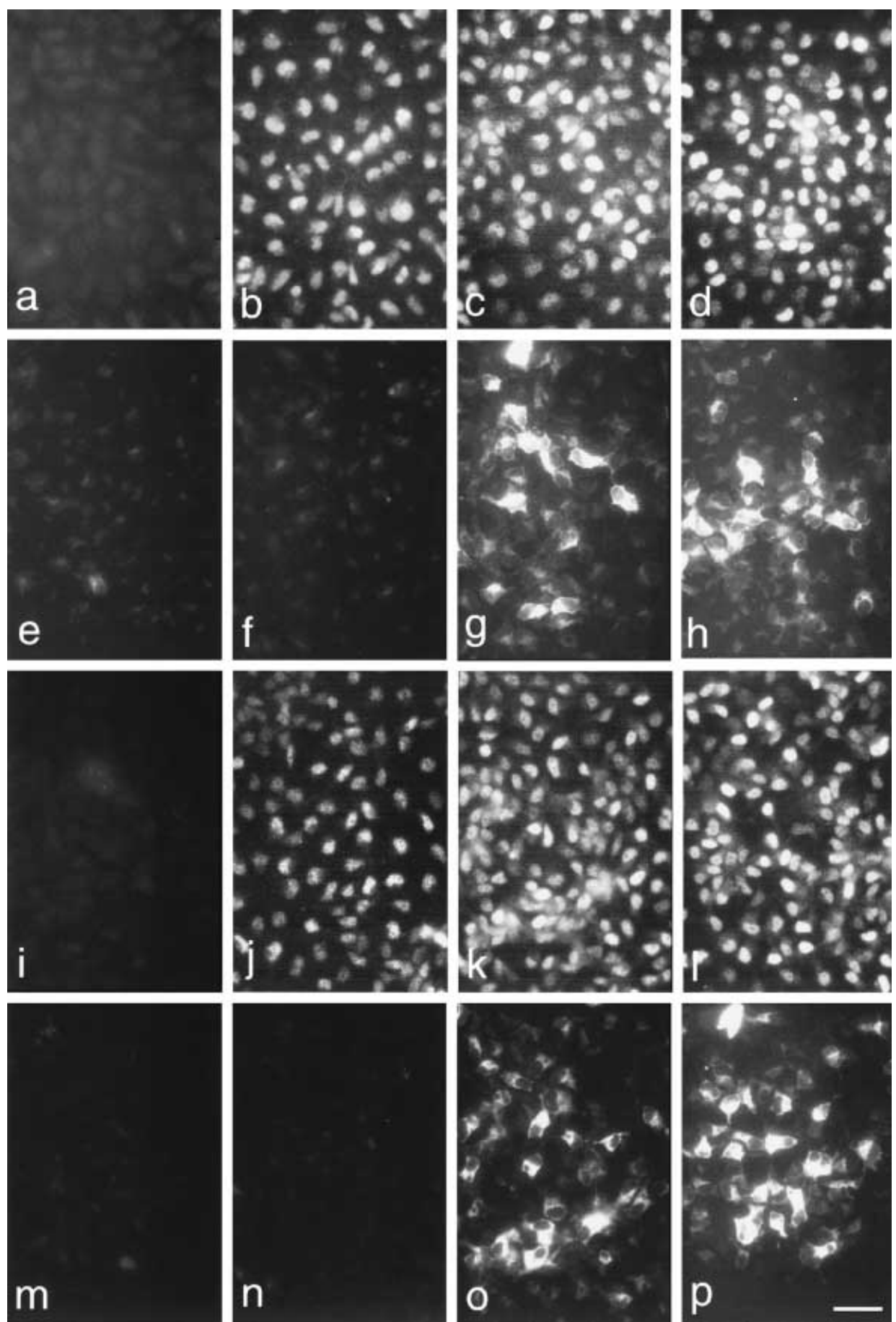

Figure 2 Time course of Pax8 and Tg re-expression in TSH or FSK/IBMX-treated PC cells. Cells were cultured for 7 days in starvation medium $(\mathrm{a}, \mathrm{e}, \mathrm{i}, \mathrm{m})$ and then treated with $1 \mathrm{mU} / \mathrm{ml} \mathrm{TSH}(\mathrm{b}-\mathrm{d}, \mathrm{f}-\mathrm{h})$ or $10 \mu \mathrm{M}$ FSK plus $1 \mathrm{mM}$ IBMX (j-l, n-p) for $6 \mathrm{~h}(\mathrm{~b}, \mathrm{f}, \mathrm{j}, \mathrm{n}), 24 \mathrm{~h}(\mathrm{c}, \mathrm{g}, \mathrm{k}, \mathrm{o})$ or $48 \mathrm{~h}(\mathrm{~d}, \mathrm{~h}, \mathrm{l}, \mathrm{p})$. Cells were fixed, permeabilized with $0 \cdot 1 \%$ Triton $\mathrm{X}-100$ and stained by indirect immunofluorescence using a polyclonal anti-Pax8 $(\mathrm{a}-\mathrm{d}, \mathrm{i}-\mathrm{l})$ antibody $(1: 300)$ or a polyclonal anti-Tg $(\mathrm{e}-\mathrm{h}, \mathrm{m}-\mathrm{p})$ antibody $(1: 5000)$. Pax8 nuclear staining was seen by $6 \mathrm{~h}$ of TSH (b) or FSK/IBMX (j) treatment. The intensity of staining was not much increased after $24 \mathrm{~h}(\mathrm{c}, \mathrm{k})$ or $48 \mathrm{~h}(\mathrm{~d}, \mathrm{I})$. Tg staining could only be detected after 24 and $48 \mathrm{~h}$ of TSH $(\mathrm{g}, \mathrm{h})$ or FSK/IBMX $(\mathrm{o}, \mathrm{p})$ treatment. Bar $=50 \mu \mathrm{m}$. 
A

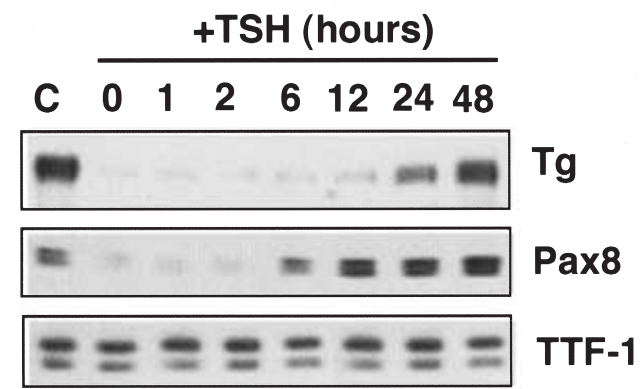

B
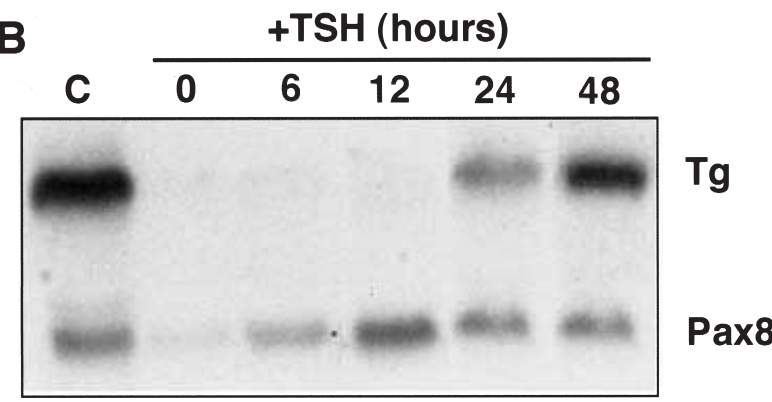

Figure 3 Detection of Pax8 and Tg proteins and mRNAs in PC cells after starvation followed by TSH stimulation. (A) PC cells were cultured in regular medium (lane $\mathrm{C}$ ) or maintained in starvation medium for 7 days (lane 0 ) and then treated with $1 \mathrm{mU} / \mathrm{ml} \mathrm{TSH}$ for different times (1, 2, 6, 12, 24 and $48 \mathrm{~h}$ ), and analyzed by Western blot to detect Pax 8 and Tg proteins. The same amount of total extract was loaded in each lane. Proteins were separated by SDS-10\% PAGE (Pax8 and TTF-1) or SDS-7\% PAGE (Tg). Pax8 protein was detected in PC control cells cultured in the presence of $6 \mathrm{H}$ (lane 0 ) and in PC cells treated with TSH for $6,12,24$ and $48 \mathrm{~h}$ following 7 days of starvation. Instead, Pax 8 was not detected 1 or $2 \mathrm{~h}$ after starvation. Tg was detected at levels comparable with those of control cells (lane C) only after 24 and $48 \mathrm{~h}$ of TSH treatment. Tg was not detected immediately after starvation (lane 0 ) or after 1, 2, 6 and $12 \mathrm{~h}$ of TSH stimulation. TTF-1 was expressed at similar levels in all culture conditions. (B) PC cells were cultured in starvation medium for 7 days and then treated with $1 \mathrm{mU} / \mathrm{ml} \mathrm{TSH}$ for $6,12,24$ and $48 \mathrm{~h}$. RNA was extracted and analyzed by Northern blot using the Pax8 and Tg probes indicated in the Material and Methods section. Following the 7 days of starvation (time 0 ) both Pax8 and Tg mRNAs were almost undetectable compared with control (C). Pax8 mRNA was detected after $6 \mathrm{~h}$ of TSH stimulation while Tg mRNA became detectable at $24 \mathrm{~h}$.

Pax8 protein with a myc tag at the $\mathrm{N}$-terminal under the control of a viral promoter, was generated. The presence of the tag allowed us to distinguish between exogenous and endogenous Pax8. When transiently transfected into HeLa cells, pEF-Pax8-myctag was able to induce the expression of a CAT gene under the control of an artificial promoter consisting of five Pax8-binding sites (CP5-CAT) thus indicating that the protein was transcriptionally active (data not shown). pEF-Pax8-myctag was then transiently transfected into PC cells cultured for 7 days in starvation medium. Forty-eight hours after transfection, cells were examined for the expression of Pax8 and Tg by indirect immunofluorescence. Cells that expressed Pax8 (myctag-positive after transfection) were still negative for Tg when probed with the anti-Tg antibody (Fig. 4), suggesting that Pax8 was not sufficient to promote $\mathrm{Tg}$ gene expression. To confirm this observation and to further analyze the role of Pax8, stable clones of PC cells, expressing pEF-Pax8-myctag, were obtained by cotransfecting the pRSV-NEO plasmid and by indirect immunofluorescence screening with an anti-myc antibody. The expression of Pax8 and Tg, in two representative clones cultured in complete medium or in starvation medium for 7 days, was analyzed by Western blot (Fig. 5). Pax8-myctag, revealed by the anti-myc antibody, was not detected in wild-type PC cells (lanes 1 and 2) while it was detected either in the presence or in the absence of serum and hormones in the two PC-Pax8-myctag clones (lanes 3-6). When analyzed with the anti-Pax8 antibody, PC cells expressed Pax8 only in the presence of hormones (lanes 1 and 2), while a Pax8 band was always detected in the PC-Pax8-myctag clones independently of culture conditions (lanes 3-6). Tg was expressed only in cells cultured in complete medium (lanes 1, 3,5) and was not detected in cells cultured in starvation medium even if Pax8-myctag was present (lanes 4, 6). These results indicate that $\mathrm{Pax} 8$ is not sufficient to activate $\mathrm{Tg}$ gene expression in PC cells cultured in the absence of TSH. Thus either Pax8 is inactive and needs to be activated by a TSH/cAMP-dependent pathway or some factors are needed, together with $\mathrm{Pax} 8$, to promote $\mathrm{Tg}$ gene expression.

Activation of the CAMP pathway is not sufficient to promote Pax8-dependent transcription in starved PC-Pax 8 cells

We then tested the hypothesis that a modification induced by the TSH/cAMP signaling cascade was needed to activate Pax8. To this purpose PC-Pax8 cells were cultured in the absence of serum and hormones and then stimulated with FSK/IBMX for different times (Fig. 6). Although the Pax8 protein was always present, still the Tg protein could not be detected at any time of FSK/IBMX stimulation (Fig. 6). These results indicate that Pax8 is unable to promote the expression of the $\mathrm{Tg}$ gene when cells are maintained in the absence of TSH, even if the cAMP signaling pathway has been activated, and suggest that, under these experimental conditions, Pax8 might be transcriptionally inactive. We therefore tested whether the transfected Pax8 was able to activate transcription from a reporter gene under the control of the $\mathrm{Tg}$ promoter (pTA-CAT3) or from the CP5-CAT reporter construct. Both pTA-CAT3 and CP5-CAT were active in PC cells and in PC-Pax8 cells cultured in complete medium while they were inactive when cells were cultured in starvation medium (Fig. 7A and B). To evaluate if, under the same experimental conditions, signaling through the TSH/ 

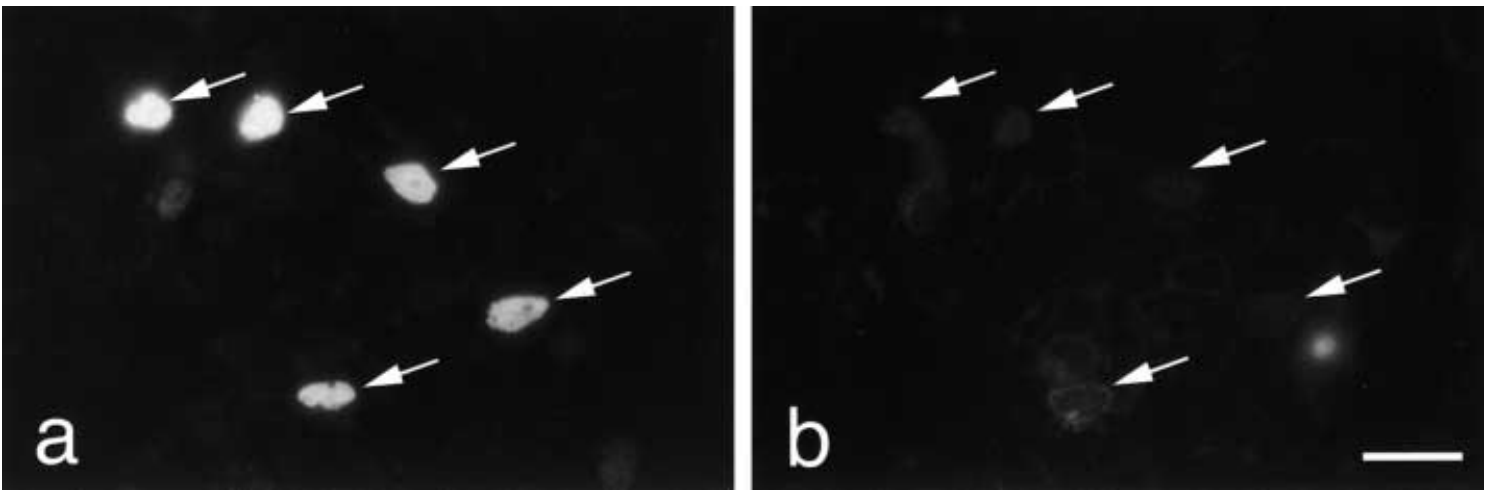

Figure 4 Transfection of Pax8 in PC cells cultured for 7 days in starvation medium does not reactivate Tg gene expression. PC cells were plated on glass coverslips, cultured for 7 days in starvation medium, and transfected with pEF-Pax8-myctag. Forty-eight hours later cells were fixed with paraformaldehyde, permeabilized with Triton X-100 and stained with a polyclonal anti-Tg (1:5000) and a monoclonal anti-myc (1:50) antibody. No Tg-positive staining (b) was detected in cells that were positive for myc staining (a). Occasional staining of Tg was observed either in transfected or in non-transfected cells. Bar $=30 \mu \mathrm{m}$.

cAMP pathway could activate the Pax8 protein, PC-Pax8 cells were cultured in starvation medium for 7 days, transiently transfected with pTA-CAT3 or CP5-CAT and stimulated with FSK/IBMX for different times (Fig. 7C). No increase in CAT activity was observed over the basal level up to $6 \mathrm{~h}$ of FSK/IBMX stimulation. These data indicate that, in cells starved of serum and hormones, Pax8 is transcriptionally inactive and that the cAMP-signaling cascade cannot activate it.

Protein synthesis is required to activate Pax8-dependent $\mathrm{Tg}$ gene expression in TSH-starved PC cells

To determine if additional factors, together with Pax8, were needed to activate TSH-dependent Tg gene expression, PC-Pax8 cells were cultured in starvation medium

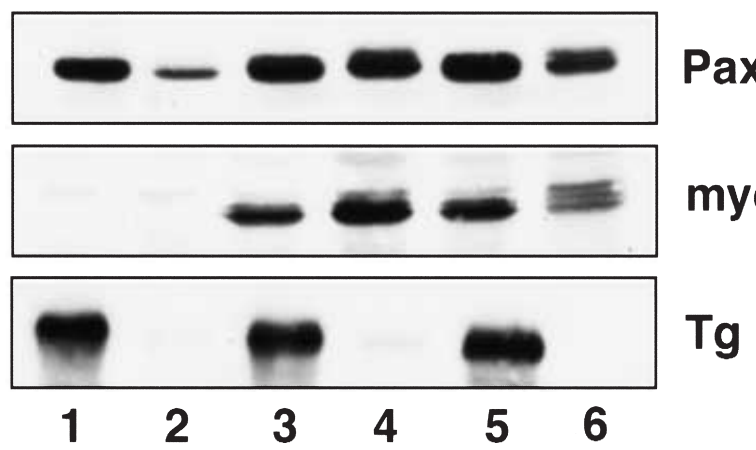

Figure 5 Western blot analysis of Pax8 and Tg proteins in PC cells and PC-Pax8 clones stably expressing Pax8-myctag. PC cells (lanes $1,2)$ and two clones of PC-Pax8 cells expressing Pax8-myctag (lanes 3-6) were cultured in regular medium (lanes 1, 3, 5) or in starvation medium for 7 days (lanes 2, 4, 6). Proteins in the cell homogenates were analyzed by Western blot as in Fig. 3 using an anti-Pax8 antibody (Pax8), an anti-myc antibody (myc) or an anti-Tg antibody (Tg). and stimulated with FSK/IBMX for different lengths of time in the presence or in the absence of cycloheximide. The expression of $\mathrm{Tg}$ in the various conditions was determined by RT-PCR. When cycloheximide was added to the medium, Tg mRNA could not be detected at any time, up to $24 \mathrm{~h}$, regardless of the presence or absence of FSK/IBMX (Fig. 8, lanes 7-12). On the contrary, Tg mRNA was clearly detected already at $12 \mathrm{~h}$ stimulation with FSK/IBMX in PC-Pax8 cells grown in the absence of cycloheximide (Fig. 8, lane 5). These data strongly indicate that the synthesis of protein(s), other than Pax8, is therefore required to activate the TSH-dependent $\operatorname{Tg}$ gene expression.

\section{Discussion}

The role of TSH in the regulation of the thyroid differentiated phenotype has been studied in several different model systems (Dumont et al. 1992). It has been demonstrated that the effects of TSH are largely mediated by the cAMP-dependent pathway and the relevance of the cAMP cascade in thyroid follicular cells has been well established (Dumont et al. 1992, Roger et al. 1995, Dremier et al. 1997). The expression of several thyroidspecific genes such as $\mathrm{Tg}$ (Avvedimento et al. 1984, Santisteban et al. 1987), TPO (Magnusson \& Rapoport 1985, Nagayama et al. 1989), TSHR (Kohn et al. 1995) and NIS (Kogai et al. 1997, Ohmori et al. 1998, Ohno et al. 1999, Spitzweg et al. 1999) has been shown to be modulated by TSH/cAMP. While in the case of the TSHR a CRE site has been shown to play an important role (Ikuyama et al. 1992, Shimura et al. 1993), and in the NIS upstream enhancer element a CRE-like site has been recently identified (Ohno et al. 1999), the situation is more complicated for the $\mathrm{Tg}$ promoter. In fact, a CRE-like 

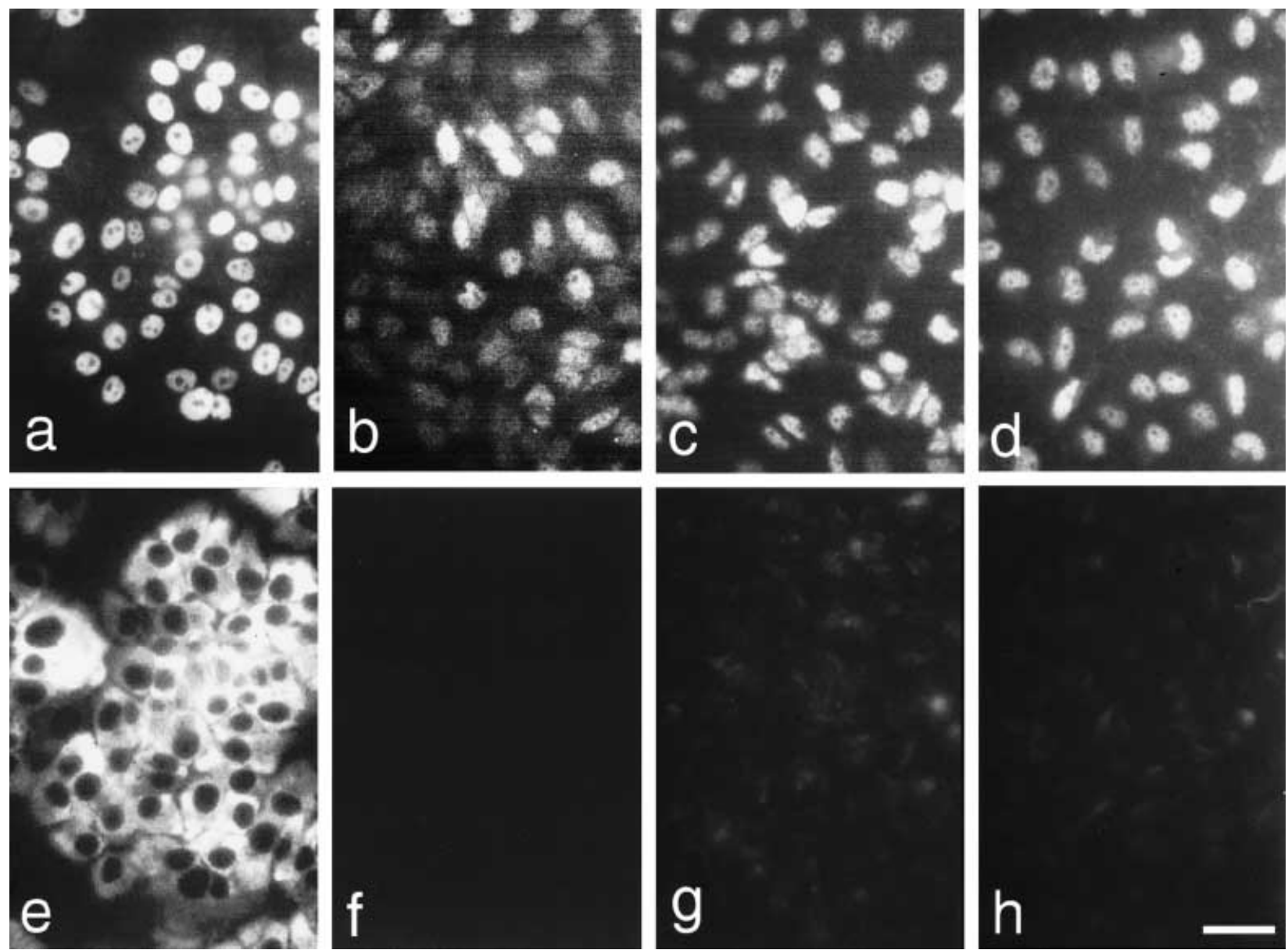

Figure 6 Pax8 and Tg expression in PC-Pax8 cells stimulated with FSK/IBMX. PC-Pax8 cells were cultured in regular medium (a, e) or in starvation medium for 7 days $(b, f)$ and then stimulated for $3 \mathrm{~h}(\mathrm{c}, \mathrm{g})$ or $5 \mathrm{~h}(\mathrm{~d}, \mathrm{~h})$ with FSK/IBMX. Pax 8 protein was detected by indirect immunofluorescence in PC-Pax8 cells by using an anti-myctag antibody (a-d). The expression of Tg was analyzed by using a polyclonal anti-Tg antibody (e-h). Bar $=40 \mu \mathrm{m}$.

consensus sequence is present in the dog and human $\mathrm{Tg}$ promoter (Christophe et al. 1989, Berg et al. 1996), but no typical cAMP-responsive element has been identified in the rat $\mathrm{Tg}$ promoter regions. Recently, it has been suggested that the thyroid-specific transcription factors TTF-1, TTF-2 and Pax8 could be the mediators of the TSH/cAMP action (Kambe \& Seo 1996). Whether the promoters of any of the thyroid-specific transcription factors contain a CRE-like sequence remains to be established. Interestingly, in FRTL5 cells Pax8 expression has been demonstrated to be increased by TSH (Fabbro et al. 1998, Medina et al. 2000) and in dog thyrocytes cAMP was shown to moderately increase Pax8 protein and mRNA levels (Van Renterghem et al. 1996).

Pax8 has been shown to be critically involved in determination and maintenance of the differentiation state of thyrocytes (Mansouri et al. 1998, Pasca Di Magliano et al. 2000). In this paper we show that also in PC rat thyroid cells in culture the expression of Pax8 is under the control of TSH/cAMP and that this control operates at a transcriptional level. We have observed that in PC cells cultured in the absence of TSH, Pax8 mRNA and protein rapidly disappear, whereas upon TSH stimulation both mRNA and protein are synthesized within $6 \mathrm{~h}$. Since $\mathrm{Tg}$ synthesis is under TSH control and Pax8 plays a key role in the regulation of thyroid-specific gene expression, we have tested the hypothesis whether Pax 8 could be the mediator of the TSH action on Tg expression. There are several lines of evidence from the literature and from our own work supporting this hypothesis: (i) Pax8 binds to the $\mathrm{Tg}$ promoter and activates transcription from $\mathrm{Tg}$ promoter reporter constructs in both thyroid and non-thyroid cells (Zannini et al. 1992, Fabbro et al. 1998); (ii) Pax8 is essential for Tg gene expression both in PC cells (Pasca Di Magliano et al. 2000) and in the mouse (Mansouri et al. 1998); (iii) Pax8 gene expression, as well as $\mathrm{Tg}$ gene 

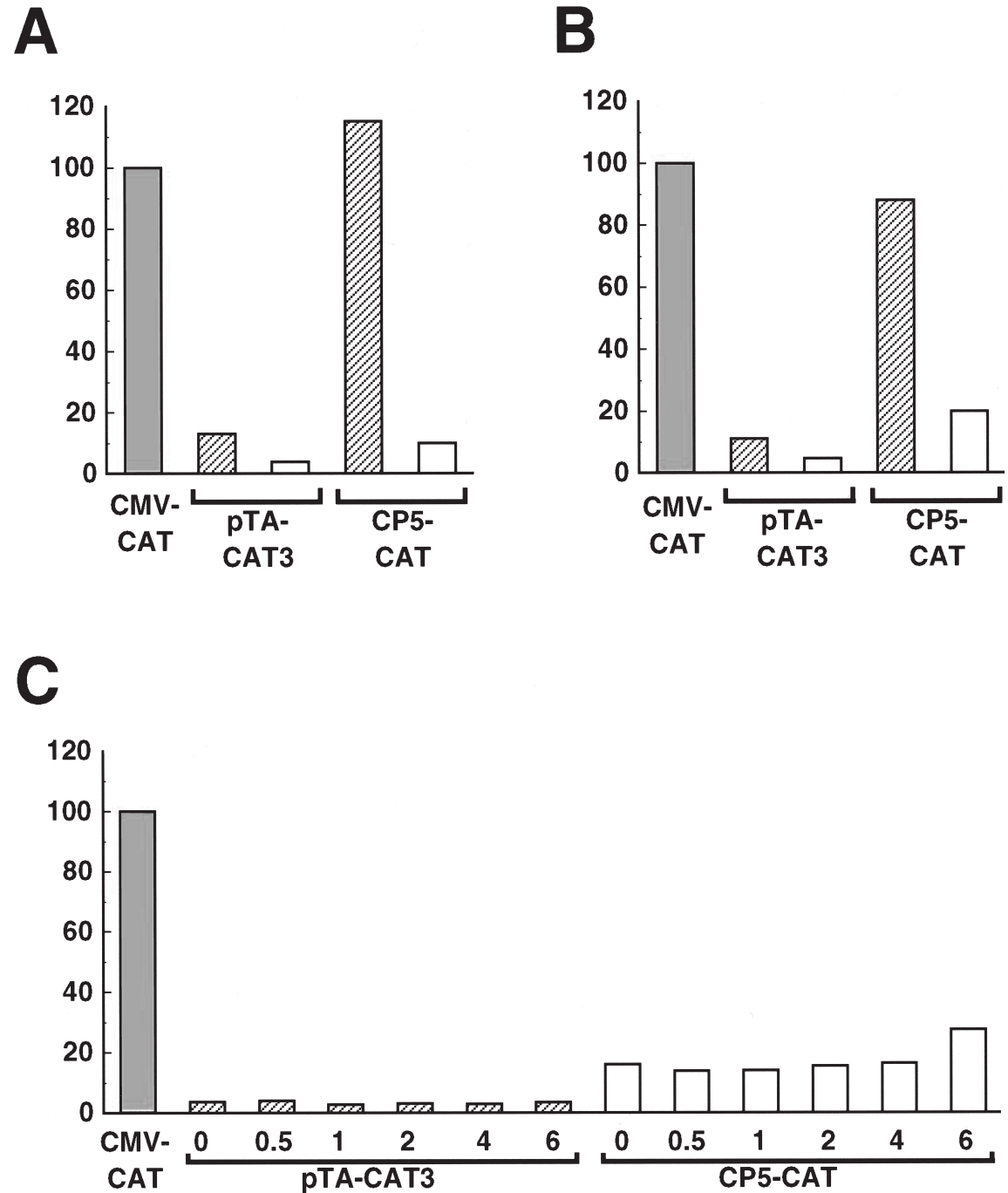

Figure 7 FSK/IBMX stimulation does not induce pTA-CAT3 and CP5-CAT promoter activity. One microgram of CMV-CAT, $10 \mu \mathrm{g}$ of pTA-CAT3 or $10 \mu \mathrm{g}$ of CP5-CAT were transfected, together with $2 \mu \mathrm{g}$ of RSV-LUC, into PC-Pax8 cells (A) and into PC wild-type cells (B) cultured either in complete medium (hatched bars) or in starvation medium (open bars). The relative activity of the pTA-CAT3 and CP5-CAT promoters is with reference to that of the CMV-CAT promoter (grey bars) which was used as control and arbitrarily set at 100. Data were normalized for transfection efficiency by determining the LUC activity and represent the average of three independent experiments. (C) PC-Pax8 cells were cultured in starvation medium for 7 days and then transfected with the same reporter constructs as in (A) and (B). Cells were stimulated with FSK/IBMX for 0.5, 1, 2, 4 and 6 h. pTA-CAT3 (hatched bars) and CP5-CAT (open bars) relative activity is with reference to that of the CMV-CAT promoter (grey bar). The data represent the average of two independent experiments.

expression, is controlled by TSH; and (iv) the TSHdependent induction of Pax8 takes place several hours before that of $\mathrm{Tg}$.

We then expressed exogenous Pax8, driven by a viral promoter, in PC cells grown in the absence of TSH and we measured $\mathrm{Tg}$ mRNA levels. Our results clearly indicate that Pax8 is not the only factor that mediates TSH action on $\mathrm{Tg}$ gene expression. In TSH-starved PC thyroid cells in culture, in fact, the expression of Pax8, either in transient or in stable transfectants, is not sufficient to promote $\mathrm{Tg}$ gene expression. Since the reactivation of the cAMP pathway, in TSH-starved cells, fully restores $\mathrm{Tg}$ synthesis, we tested whether a cAMP-dependent modification was needed to activate Pax 8 protein. Our experiments demonstrate that this is not the case; in thyroid cells on TSH starvation a cAMP-dependent 


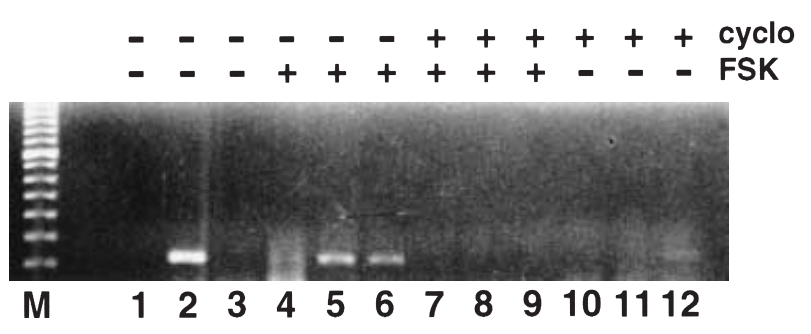

Figure 8 Requirement of protein synthesis in Tg gene activation. PC-Pax8 cells were cultured in complete medium (lane 2) or maintained for 7 days in starvation medium (lane 3 ) and treated for 6, 12 or $24 \mathrm{~h}$ with FSK/IBMX in the absence (lanes 4-6) or in the presence (lanes 7-9) of cycloheximide. Tg mRNA was detected by RT-PCR using two oligonucleotides located respectively in the first and second exon of the Tg gene. RT-PCR products were separated on a $1 \%$ agarose gel. Tg mRNA can be detected in control cells cultured in complete medium (lane 2) or after 12 and $24 \mathrm{~h}$ of FSK/IBMX treatment in the absence of cycloheximide (lanes 5,6). Tg mRNA was not detected in HeLa cells (lane 1), in PC-Pax8 cells cultured in starvation medium for 7 days (lane 3 ) and in cells maintained in the presence of cycloheximide either treated (lanes 7-9) or not treated (lanes 10-12) with FSK/IBMX.

modification of Pax8, or of any other factor involved in $\mathrm{Tg}$ gene expression, is not sufficient to activate the Tg gene promoter. We suggest that an additional factor yet unknown, whose synthesis is induced by cAMP, is necessary, together with $\mathrm{Pax} 8$, to promote $\mathrm{Tg}$ gene transcription. Furthermore, we demonstrated, by using a Pax8-dependent artificial promoter, that Pax8 protein is transcriptionally inactive in the absence of cAMP stimulation.

How can we explain Pax8 inability to activate transcription in TSH-deprived PC cells? Several hypotheses can be made. On the one hand, it can be hypothesized that one or more factors required to activate Pax 8 are missing in TSH-starved thyroid cells. We demonstrated that to restore Pax8 transcriptional activity, the TSH/cAMPstimulated synthesis of additional protein(s) is required. This putative factor(s) could act directly on Pax8, since in TSH-starved thyroid cells, Pax8, as well as being unable to activate a $\mathrm{Tg}$ gene promoter, is also unable to activate an artificial promoter consisting of five Pax8-binding sites, thus suggesting that Pax8 itself is inactive. In addition, it also possible that a yet unidentified factor, whose expression is controlled by the TSH/cAMP pathway, is necessary together with Pax8 to activate the Tg promoter. On the other hand, we can speculate that other factors are inactivating Pax8 either by directly binding or by reversibly modifying it. Some of the presumptive inhibitors and/or activators are tissue-specific proteins and some of them are likely to directly interact with Pax8. The identification of Pax8 interacting proteins will clarify this issue.

The Pax8-binding site on the Tg promoter overlaps one of the TTF-1-binding sites, thus it could be argued that
TTF-1 is a candidate for acting as a Pax8 modulator. It has been suggested that a specific ratio of TTF- $1 / \operatorname{Pax} 8$ is needed to activate $\mathrm{Tg}$ gene promoter (Fabbro et al. 1998). It has also been indicated that TTF-1 expression is under hormonal regulation; TSH, possibly in the presence of insulin or serum, was shown to decrease TTF-1 levels (Saito et al. 1997). In our experiments, however, no change in TTF-1 levels are observed in the different culture conditions. Another potential candidate could be the transcription factor TTF-2, since it is a thyroid-specific transcription factor and its expression also depends upon TSH (Ortiz et al. 1997, Zannini et al. 1997). However, the data on TTF-2 present in the literature are quite controversial. Initially TTF-2 was suggested to be important for Tg transcription (Santisteban et al. 1992) but subsequently it was demonstrated that in both thyroid and non-thyroid cells TTF-2 acts as a promoter-specific repressor (Perrone et al. 2000). In addition, we have to consider that in our experiments Pax8 is not able to activate transcription from the CP5 promoter, whose activation depends only upon Pax8.

When is the TSH/cAMP control of Pax8 established? Pax8 is a factor that plays a double role; in the mouse, during embryonic development, it is required for correct thyroid organogenesis, as indicated by the finding that Pax8 knockout mice do not have thyroid follicular cells (Mansouri et al. 1998), and it is responsible for the maintenance of differentiated functions in thyroid cells in culture (Pasca Di Magliano et al. 2000). Although not proven, these two functions are possibly independent as suggested by the fact that the expression of a functional Pax8 at E10.5 does not induce Tg gene expression while already playing a role in thyrocytes survival and proliferation. The role of Pax8 in follicular cell formation during organogenesis might be TSH-independent; mutations in the TSH receptor (hyt/hyt mouse) (Green et al. 1988, Anthony et al. 1993) that impair the cell response to TSH and cause hypothyroidism do not impair thyroid follicle formation or $\mathrm{Tg}$ and Pax8 expression (M De Felice, unpublished observations). Therefore, surprisingly, Pax8 appears to be functionally active during thyroid development despite the lack of thyrocyte response to TSH. Interestingly, it has recently been reported that the thyroid-specific expression of a dominant-negative CREB isoform in transgenic mice causes impairment of thyroid function, failure of follicular cells differentiation, and alteration of the expression of thyroid-specific genes and TTFs (Nguyen et al. 2000). Presumably the effect of the dominant-negative CREB is an inhibition of the TSH signaling pathway downstream of the receptor itself. Because CREB can be activated by various other signaling cascades (Andrisani 1999), the apparent discrepancy between the data obtained in the hyt/hyt mouse model and in the CREB dominant-negative transgenics suggested that in the former the selective inhibition of the TSH pathway at the level of the receptor is not 
sufficient to impair CREB, while instead it occurs in the latter.

Loss-of-function mutations of the TSH receptor have been implicated in the pathogenesis of thyroid diseases. In some patients carrying an inactivating mutation of the $\mathrm{TSH}$ receptor, plasma $\mathrm{Tg}$ levels were in the normal range and were in fact disproportionately high considering the small size of the patients' thyroids (Gagne et al. 1998). It is known that TSH is not required for the development and migration of the thyroid anlage, but it is essential for thyroid growth and function. The possible mechanisms for $\mathrm{Tg}$ secretion in the absence of TSH action have been discussed in the literature (Abramowicz et al. 1997). The presence of circulating $\mathrm{Tg}$ in these patients may indicate that some synthesis of $\mathrm{Tg}$ is still occurring. Alternatively, it could result from incomplete polarization of thyrocytes, from abnormal routing of $\mathrm{Tg}$, or from intercellular leakage from dysplastic follicles. Of note, recently it has been reported the case of a patient carrying a new loss-of-function mutation of the TSH receptor, with no detected levels of circulating Tg (Tonacchera et al. 2000).

Thus, the mechanisms by which TSH and cAMP regulate thyroid differentiation are at present still not completely understood, and we should like to suggest that TSH-mediated regulation of transcription is likely to be a complex phenomenon involving several different mechanisms.

\section{Acknowledgements}

This work was supported by grants from the Consiglio Nazionale delle Ricerche 'Target project on biotechnology', the Ministero per l'Universita e la Ricerca Scientifica (MURST) project 'Molecular mechanisms responsible for differentiation of thyroid cells: diagnostic and therapeutic applications', the CNR Progetto Strategico 'Modifiche post-trascrizionali dell'espressione genica', and the Programma Biotecnologie legge 95/95 (MURST 5\%).

\section{References}

Abramowicz MJ, Duprez L, Parma J, Vassart G \& Heinrichs C 1997 Familial congenital hypothyroidism due to inactivating mutation of the thyrotropin receptor causing profound hypoplasia of the thyroid gland. Journal of Clinical Investigation 99 3018-3024.

Ambesi-Impiombato FS \& Coon HG 1979 Thyroid cells in culture. International Review of Cytology 10 163-172.

Andrisani OM 1999 CREB-mediated transcriptional control. Critical Reviews in Eukaryotic Gene Expression 9 19-32.

Anthony A, Adams PM \& Stein SA 1993 The effects of congenital hypothyroidism using the hyt/hyt mouse on locomotor activity and learned behavior. Hormones and Behaviour 27 418-433.

Avvedimento VE, Tramontano D, Ursini MV, Monticelli A \& Di Lauro R 1984 The level of thyroglobulin mRNA is regulated by TSH both in vitro and in vivo. Biochemical and Biophysical Research Communications 122 472-477.
Berg V, Vassart G \& Christophe D 1996 Identification of a thyroidspecific and CAMP-responsive enhancer in the upstream sequences of the human thyroglobulin promoter. Biochimica et Biophysica Acta 1307 35-38.

Chebath J, Chabaud O \& Mauchamp J 1979 Modulation of thyroglobulin messenger RNA level by thyrotropin in cultured thyroid cells. Nucleic Acids Research 6 3353-3367.

Chomczynski P \& Sacchi N 1987 Single step method of RNA isolation by acid guanidinium thiocyanate-phenol-chloroform extraction. Analytical Biochemistry 162 156-159.

Christophe D, Gerard C, Juvenal G, Bacolla A, Teugels E, Ledent C, Christophe-Hobertus C, Dumont JE \& Vassart G 1989 Identification of a cAMP-responsive region in thyroglobulin gene promoter. Molecular and Cellular Endocrinology 64 5-18.

Church GM \& Gilbert W 1984 Genomic sequencing. PNAS 81 1991-1995.

Damante G \& Di Lauro R 1994 Thyroid-specific gene expression. Biochimica et Biophysica Acta 1218 255-266.

Damante G, Tell G \& Di Lauro R 2000 A unique combination of transcription factors controls differentiation of thyroid cells. Progress in Nucleic Acid Research and Molecular Biology 66 307-356.

De Vita G, Zannini M, Cirafici AM, Melillo RM, Di Lauro R, Fusco A \& Santoro M 1998 Expression of the RET/PTC1 oncogene impairs the activity of TTF- 1 and Pax- 8 thyroid transcription factors. Cell Growth and Differentiation 9 97-103.

Dremier S, Pohl V, Poteet-Smith C, Roger PP, Corbin J, Doskeland SO, Dumont JE \& Maenhaut C 1997 Activation of cyclic AMPdependent kinase is required but may not be sufficient to mimic cyclic AMP-dependent DNA synthesis and thyroglobulin expression in dog thyroid cells. Molecular and Cellular Biology 17 6717-6726.

Dumont JE, Lamy F, Roger P \& Maenhaut C 1992 Physiological and pathological regulation of thyroid cell proliferation and differentiation by thyrotropin and other factors. Physiological Reviews 72 667-697.

Fabbro D, Pellizzari L, Mercuri F, Tell G \& Damante G 1998 Pax-8 protein levels regulate thyroglobulin gene expression. Journal of Molecular Endocrinology 21 347-354.

Fusco A, Berlingieri M, Di Fiore P, Portella G, Grieco M \& Vecchio G 1987 One- and two-step transformation of rat thyroid epithelial cells by retroviral oncogenes. Molecular and Cellular Biology 2 $3365-3370$

Gagne N, Parma J, Deal C, Vassart G \& Van Vliet G 1998 Apparent congenital athyreosis contrasting with normal plasma thyroglobulin levels and associated with inactivating mutations in the thyrotropin receptor gene: are athyreosis and ectopic thyroid distinct entities? Journal of Clinical Endocrinology and Metabolism 83 1771-1775.

Gerard CM, Lefort A, Christophe D, Libert F, Van Sande J, Dumont JE \& Vassart G 1989 Control of thyroperoxidase and thyroglobulin transcription by cAMP: evidence for distinct regulatory mechanisms. Molecular Endocrinology 3 2110-2118.

Green RP, Birkenmeier EH, Beamer WG, Maltais LJ \& Gordon JI 1988 The hypothyroid (hyt/hyt) mouse: a model system for studying the effects of thyroid hormone on developmental changes in gene expression. PNAS 85 5592-5596.

Ikuyama S, Niller HH, Shimura H, Akamizu T \& Kohn LD 1992 Characterization of the $5^{\prime}$-flanking region of the rat thyrotropin receptor gene. Molecular Endocrinology 6 793-804.

Kambe F \& Seo H 1996 Mediation of the hormone- and serumdependent regulation of thyroglobulin gene expression by thyroidtranscription factors in rat thyroid FRTL-5 cells. Journal of Endocrinology 150 287-298.

Kambe F, Nomura Y, Okamoto T \& Seo H 1996 Redox regulation of thyroid-transcription factors, Pax- 8 and TTF-1, is involved in their increased DNA-binding activities by thyrotropin in rat thyroid FRTL-5 cells. Molecular Endocrinology 10 801-812. 
Kogai T, Endo T, Saito T, Miyazaki A, Kawaguchi A \& Onaya T 1997 Regulation by thyroid-stimulating hormone of sodium/iodide symporter gene expression and protein levels in FRTL-5 cells. Endocrinology 138 2227-2232.

Kohn LD, Shimura H, Shimura Y, Hidaka A, Giuliani C, Napolitano G, Ohmori M, Laglia G \& Saji M 1995 The thyrotropin receptor. Vitamins and Hormones 50 287-384.

Kurihara H, Uchida K \& Fujita H 1990 Distribution of microtubules and microfilaments in thyroid follicular epithelial cells of normal, TSH-treated, aged, and hypophysectomized rats. Histochemistry 93 335-345.

Lazzaro D, Price M, de Felice M \& Di Lauro R 1991 The transcription factor TTF-1 is expressed at the onset of thyroid and lung morphogenesis and in restricted regions of the foetal brain. Development 113 1093-1104.

Lee NT, Kamikubo K, Chai KJ, Kao LR, Sinclair AJ, Nayfeh SN \& Chae CB 1991 The deoxyribonucleic acid regions involved in the hormonal regulation of thyroglobulin gene expression. Endocrinology 128 111-118.

Macchia PE, Lapi P, Krude H, Pirro MT, Missero C, Chiovato L, Souabni A, Baserga M, Tassi V, Pinchera A, Fenzi G, Gruters A, Busslinger M \& Di Lauro R 1998 PAX8 mutations associated with congenital hypothyroidism caused by thyroid dysgenesis. Nature Genetics 19 83-86.

Magnusson RP \& Rapoport B 1985 Modulation of differentiated function in cultured thyroid cells: thyrotropin control of thyroid peroxidase activity. Endocrinology 116 1493-1500.

Mansouri A, Chowdhury K \& Gruss P 1998 Follicular cells of the thyroid gland require Pax8 gene function. Nature Genetics 19 87-90.

Mascia A, De Felice M, Lipardi C, Gentile R, Cali G, Zannini M, Di Lauro R \& Nitsch L 1997 Transfection of TTF-1 gene induces thyroglobulin gene expression in undifferentiated FRT cells. Biochimica et Biophysica Acta 1354 171-181.

Medina DL, Suzuki K, Pietrarelli M, Okajima F, Kohn LD \& Santisteban P 2000 Role of insulin and serum on thyrotropin regulation of thyroid transcription factor- 1 and pax- 8 genes expression in FRTL-5 thyroid cells. Thyroid 10 295-303.

Missero C, Cobellis G, De Felice M \& Di Lauro R 1998 Molecular events involved in differentiation of thyroid follicular cells. Molecular and Cellular Endocrinology 140 37-43.

Nagayama Y, Yamashita S, Hirayu H, Izumi M, Uga T, Ishikawa N, Ito K \& Nagataki S 1989 Regulation of thyroid peroxidase and thyroglobulin gene expression by thyrotropin in cultured human thyroid cells. Journal of Clinical Endocrinology and Metabolism 68 $1155-1159$.

Nguyen LQ, Kopp P, Martinson F, Stanfield K, Roth SI \& Jameson JL 2000 A dominant negative CREB (cAMP response elementbinding protein) isoform inhibits thyrocyte growth, thyroid-specific gene expression, differentiation, and function. Molecular Endocrinology 14 1448-1461.

Ohmori M, Endo T, Harii N \& Onaya T 1998 A novel thyroid transcription factor is essential for thyrotropin-induced up-regulation of $\mathrm{Na}^{+} / \mathrm{I}^{-}$symporter gene expression. Molecular Endocrinology 12 $727-736$.

Ohno M, Zannini M, Levy O, Carrasco N \& di Lauro R 1999 The paired-domain transcription factor Pax8 binds to the upstream enhancer of the rat sodium/iodide symporter gene and participates in both thyroid-specific and cyclic-AMP-dependent transcription. Molecular and Cellular Biology 19 2051-2060.

Ortiz L, Zannini M, Di Lauro R \& Santisteban P 1997 Transcriptional control of the forkhead thyroid transcription factor TTF-2 by thyrotropin, insulin, and insulin-like growth factor I. Journal of Biological Chemistry 272 23334-23339.

Paire A, Bernier-Valentin F, Selmi-Ruby S \& Rousset B 1997 Characterization of the rat thyroid iodide transporter using antipeptide antibodies. Relationship between its expression and activity. Journal of Biological Chemistry 272 18245-18249.
Pasca Di Magliano M, Di Lauro R \& Zannini M 2000 Pax8 has a key role in thyroid cell differentiation. PNAS 97 13144-13149.

Perrone L, Pasca di Magliano M, Zannini M \& Di Lauro R 2000 The thyroid transcription factor 2 (TTF-2) is a promoter-specific DNA-binding independent transcriptional repressor. Biochemical and Biophysical Research Communications 275 203-208.

Plachov D, Chowdhury K, Walther C, Simon D, Guenet JL \& Gruss P 1990 Pax8, a murine paired box gene expressed in the developing excretory system and thyroid gland. Development 110 643-651.

Roger PP, Reuse S, Maenhaut C \& Dumont JE 1995 Multiple facets of the modulation of growth by cAMP. Vitamins and Hormones $\mathbf{5 1}$ 59-191.

Roger PP, Christophe D, Dumont JE \& Pirson I 1997 The dog thyroid primary culture system: a model of the regulation of function, growth and differentiation expression by cAMP and other well-defined signaling cascades. European Journal of Endocrinology 137 $579-598$.

Saito T, Endo T, Nakazato M, Kogai T \& Onaya T 1997 Thyroidstimulating hormone-induced down-regulation of thyroid transcription factor 1 in rat thyroid FRTL-5 cells. Endocrinology 138 602-606.

Santisteban P, Kohn LD \& Di Lauro R 1987 Thyroglobulin gene expression is regulated by insulin and insulin-like growth factor I, as well as thyrotropin, in FRTL-5 thyroid cells. Journal of Biological Chemistry 262 4048-4052.

Santisteban P, Acebron A, Polycarpou-Schwarz M \& Di Lauro R 1992 Insulin and insulin-like growth factor I regulate a thyroidspecific nuclear protein that binds to the thyroglobulin promoter. Molecular Endocrinology 6 1310-1317.

Shimura H, Ikuyama S, Shimura Y \& Kohn LD 1993 The cAMP response element in the rat thyrotropin receptor promoter. Regulation by each decanucleotide of a flanking tandem repeat uses different, additive, and novel mechanisms. Journal of Biological Chemistry 268 24125-24137.

Sinclair AJ, Lonigro R, Civitareale D, Ghibelli L \& Di Lauro R 1990 The tissue-specific expression of the thyroglobulin gene requires interaction of thyroid-specific and ubiquitous factors. European Journal of Biochemistry 193 311-318.

Spitzweg C, Joba W, Morris JC \& Heufelder AE 1999 Regulation of sodium iodide symporter gene expression in FRTL-5 rat thyroid cells. Thyroid 9 821-830.

Tonacchera M, Agretti P, Pinchera A, Rosellini V, Perri A, Collecchi P, Vitti P \& Chiovato L 2000 Congenital hypothyroidism with impaired thyroid response to thyrotropin (TSH) and absent circulating thyroglobulin: evidence for a new inactivating mutation of the TSH receptor gene. Journal of Clinical Endocrinology and Metabolism 85 1001-1008.

Tosta Z, Chabaud O \& Chebath J 1983 Identification of thyroglobulin mRNA sequences in the nucleus and the cytoplasm of cultured thyroid cells: a post-transcriptional effect of thyrotropin. Biochemical and Biophysical Research Communications 116 54-61.

Tramontano D, Avivi A, Ambesi-Impiombato FS, Barak L, Geiger B \& Schlessinger J 1982 Thyrotropin induces changes in the morphology and the organization of microfilament structures in cultured thyroid cells. Experimental Cell Research 137 269-275.

Van der Kallen CJ, Spierings DC, Thijsse JH, Blankenstein MA \& de Bruin TW 1996 Disrupted co-ordination of Pax-8 and thyroid transcription factor-1 gene expression in a dedifferentiated rat thyroid tumour cell line derived from FRTL-5. Journal of Endocrinology 150 377-382.

Van Heuverswyn B, Streydio C, Brocas H, Refetoff S, Dumont J \& Vassart G 1984 Thyrotropin controls transcription of the thyroglobulin gene. PNAS 81 5941-5945.

Van Heuverswyn B, Leriche A, Van Sande J, Dumont JE \& Vassart G 1985 Transcriptional control of thyroglobulin gene expression by cyclic AMP. FEBS Letters 188 192-196. 
Van Renterghem P, Dremier S, Vassart G \& Christophe D 1995 Study of TTF-1 gene expression in dog thyrocytes in primary culture. Molecular and Cellular Endocrinology 112 83-93.

Van Renterghem P, Vassart G \& Christophe D 1996 Pax 8 expression in primary cultured dog thyrocyte is increased by cyclic AMP. Biochimica et Biophysica Acta 1307 97-103.

Westermark B \& Portor KR 1982 Hormonally induced changes in the cytoskeleton of human thyroid cells in culture. Journal of Cell Biology 94 42-50.

Zannini M, Francis-Lang H, Plachov D \& Di Lauro R 1992 Pax-8, a paired domain-containing protein, binds to a sequence overlapping the recognition site of a homeodomain and activates transcription from two thyroid-specific promoters. Molecular and Cellular Biology 12 4230-4241.

Zannini M, Avantaggiato V, Biffali E, Arnone MI, Sato K, Pischetola M, Taylor BA, Phillips SJ, Simeone A \& Di Lauro R 1997 TTF-2, a new forkhead protein, shows a temporal expression in the developing thyroid which is consistent with a role in controlling the onset of differentiation. EMBO Journal 16 3185-3197.

Received 12 June 2001

Accepted 11 September 2001 